\title{
Gharacterization of a Propionic Acid Producing Actinomycete, Actinomyces propionicus, Sp.nov.
}

\author{
By B. B. BUCHANAN AND L. PINE \\ Department of Microbiology, Duke University Medical School, \\ Durham, North Carolina, U.S.A.
}

(Received 28 August 1961)

\begin{abstract}
SUMMARY
An anaerobic actinomycete isolated from the lachrymal duct of a case of human lachrymal canaliculitis is described. Although the organism was described previously as Actinomyces israelii, more recent observations show it differs significantly from members of this genus in metabolism, physiology and cell-wall composition. The organism is similar to the Actinomyces in its production of true branching mycelial elements in vivo and in vitro, catalase negativity, pathogenicity for experimental animals, and amino acid cell-wall composition. It is similar to the propionic acid bacteria in its fermentation of glucose to propionate, acetate, and $\mathrm{CO}_{2}$, its morphological variation, formation of a dull orange colour, and the presence of diaminopimelic acid in its cell wall. Other characteristics such as the formation of DL-lactic acid, absence of a $\mathrm{CO}_{2}$ requirement either anaerobically or aerobically, inability to ferment glycerol or lactate, and sugar and amino sugar composition of the cell wall also serve to differentiate this organism from other strains of Actinomyces and from Propionibacterium. In view of these observations the organism is reclassified and named $A$. propionicus, sp.nov. The possible phylogenetic relation of $A$. propionicus to certain other branching filamentous organisms is discussed.
\end{abstract}

\section{IN'TRODUCTION}

From studies of human canaliculitis, Pine \& Hardin (1959) and Pine, Hardin, Roberts \& Turner (1960) have described two of the etiological agents as Actinomyces israelii. Both organisms were found to possess morphological and physiological characters typical of the species. However, one of the organisms, strain 699, fermented glucose to form propionic acid in addition to the acetic, formic, lactic, and succinic acids described for other strains (Pine \& Howell, 1956). Because of this difference, the morphological, physiological and biochemical characteristics of strain 699 have been studied further. Although strain 699 possessed many of the characters of recognized species of Actinomyces (Bergey's Manual, 1957; Howell, Murphy, Paul \& Stephan, 1959; Pine, Howell \& Watson, 1960; Waksman, 1961) the more recent findings showed it had major differences in metabolism, physiology, and cell-wall composition. In many respects it was closely related to members of the genus Propionibacterium. After consideration of these findings we were unable to assign the organism to a previously described species of either of these genera. As a result, we have concluded that the organism warrants inclusion in the genus Actinomyces and propose the name Actinomyces propionicus, sp.nov. 


\section{METHODS}

Actinomyces propionicus ( $A$. israelii, strain 699 ) was isolated as described previously by Pine \& Hardin (1959). Sources of other species of Actinomyces were described by Pine, Howell \& Wat:ion (1960). Propionibacterium arabinosum, 4965, and $\boldsymbol{P}$. pentosaceum, 4875, were olstained from the American Type Culture Collection. The Casitone medium of Pin \& Watson (1959) with no added lipoic acid was used throughout this study. The procedures for the preparation of inocula and growth were those described by $\mathbf{H}$ well \& Pine (1956).

\section{Methods of growth studies}

Amounts of growth were determined by preparing a 1/10 or 1/20 dilution of homogenized cultures with distilled water and reading the absorbancy at $660 \mathrm{~m} \mu$ on a Spectronic-20 colorimeter ayainst a corresponding dilution of uninoculated medium. One growth unit $=$ op ical density unit divided by the dilution, and was equivalent to $\mathbf{0 . 3} \mathrm{mg}$. dry wt. organism. Forty-eight hr. cultures of Actinomyces bovis (P1S) and $A$. naeslundii (27) and $72 \mathrm{hr}$. cultures of $A$. propionicus and $A$. israelii (895) were diluted with sterile distilled water to an optical density $=0.5$ on a Spectronic-20 colorimeter. Tes: tubes containing $5 \mathrm{ml}$. Casitone medium were inoculated with one drop of this suspension. Anaerobic cultures were incubated under a pyrogallol $+\mathrm{Na}_{2} \mathrm{CO}_{3}$ seal. Aerobic cultures were either unsealed or sealed with $\mathrm{KH}_{2} \mathrm{PO}_{4}(\mathrm{M})+\mathrm{Na}_{2} \mathrm{CO}_{3}(10 \%, \mathrm{w} / \mathrm{v})$ as indicated and incubated on a rotary shaker. All incubations were conclucted at $37^{\circ}$.

The methods used to determine fermentative and physiological characters were as previously described (Pinc: \& Howell, 1956). The size of inoculum required for aerobic growth was determined according to the procedure of Howell et al. (1959).

For pathogenicity studies, orginisms from $72 \mathrm{hr}$. cultures of Actinomyces spp. and from $48 \mathrm{hr}$. cultures of Prox ionibacterium were harvested by centrifugation and washed twice with sterile distilled water. Packed organisms $(0.5 \mathrm{ml}$.) were brought to a volume of $5 \mathrm{ml}$. with physiological saline $(\mathrm{NaCl}, 0.85 \%$, w/v). White female mice ranging from 5 to 6 weeks of age were inoculated intraperitoneally with $0.2 \mathrm{ml}$. or $0.5 \mathrm{ml}$. of this suspension, depending upon the experiment. After 18 days animals were sacrificed and examined for internal lesions. When lesions were found these were recorded, isolation plates were streaked with pus, and Gram stains of the pus made. Isolations were made on brain heat infusion agar (Difco) plates which were incubated 1-3 cays under an atmosphere of $5 \%(\mathrm{v} / \mathrm{v}) \mathrm{CO}_{2}-95 \%$ $(\mathrm{v} / \mathrm{v}) \mathrm{N}_{2}$.

For product analysis fermentations were carried out in duplicate; one of each duplicate contained uniformly lakelled ${ }^{14} \mathrm{C}$-glucose of known specific activity. All fermentation vessels were inoculated with $2 \mathrm{mg}$. equivalent of dry wt. organism and incubated for 3 days at $37^{\circ}$. For anaerobic studies, the organisms were grown in fermentation tubes (Pine \& Howell, 1956) containing $50 \mathrm{ml}$. of medium. Tubes were sealed with $1 \mathrm{ml}$. each of $\mathrm{Na}_{2} \mathrm{CO}_{3}+$ pyrogallol or $\mathrm{NaOH}+$ pyrogallol. For aerobic studies organisms were grown or a rotary shaker in a $160 \mathrm{ml}$. Erlenmeyer flask containing $50 \mathrm{ml}$. medium and sto opered with a vaccine stopper. At the end of the 
incubation period $1 \mathrm{ml}$. of $50 \%(\mathrm{w} / \mathrm{v}) \mathrm{CO}_{2}$-free $\mathrm{NaOH}$ was injected through the vaccine stopper to make the liquor strongly alkaline.

Carbon dioxide was determined manometrically by the method of Peters \& Van Slyke (1932). Volatile acids were quantitatively estimated by the method of Friedemann (1938) as modified by Rabinowitz \& Barker (1956). After formate oxidation, propionate and acetate concentrations were calculated by solving simultaneous equations based on Duclaux values. Glucose was determined by the method of Folin \& Malmros as given by Umbreit, Burris \& Stauffer (1957).

Succinate and lactate were quantitatively estimated from fermentations conducted with radioactive glucose. They were collected by $48 \mathrm{hr}$. ether extraction and separated and identified by means of a Dowex-1 column with a formic acid gradient according to a method modified from that of Busch, Hurlbert \& Potter (1952). 'This method effects repeatable separation of lactic and succinic acids with no overlapping of peaks. The formic acid eluant was removed by evaporation on a steam bath, and the non-volatile acids were quantitatively determined by titration with $0 \cdot 1 \mathrm{~N}-\mathrm{NaOH}$ to the phenol red end-point.

Glucose incorporation into cellular material was calculated from organisms grown on ${ }^{14} \mathrm{C}$-labelled glucose which were collected by centrifugation, washed 5 times with distilled water, pipetted on to planchets and dried under infrared heat. Samples were counted at infinite thinness. Radioactivity was measured with a continuous flow counter equipped with a 'micromil' window (Nuclear-Chicago).

The lactic acid used for determination of optical rotation was obtained from a 6 l. flask of fermentation liquor. The flask contained a modified Casitone medium in which acid-hydrolysed casein (Nutritional Biochemical Co., Cleveland, Ohio) was substituted for Casitone and the minor-element solution omitted. Lactate was collected by $48 \mathrm{hr}$. ether extraction and crystallized as the zinc salt (Pederson, Peterson \& Fred, 1926). Optical activity was determined with a solution of zine lactate in a Model BO polarimeter (O.C. Rudolph and Sons Inc., Caldwell, N.J.).

Cell walls were isolated and acid-hydrolysed according to the method of Cummins $\&$ Harris (1956). In most cases amino acids and amino sugars were identified solely by $\mathbf{R}_{f}$ values on two-dimensional paper chromatograms developed as described by these investigators. Diaminopimelic acid and lysine were more definitely identified by co-chromatography with known compounds. Sugars as well as amino sugars were identified by $\mathbf{R}_{f}$ values from unidirectional paper chromatograms developed in butanol + pyridine + water $(6+4+3$ by vol $)$ and butanol + acetic acid + water $(5+$ $1+2$ by vol). Sugar and amino sugar spots were located on duplicate sheets and were characterized by their comparative reactions using a modified silver nitrate dip (Dr R. W. Wheat, unpublished results) and a ninhydrin spray $(0 \cdot 25 \%, \mathrm{w} / \mathrm{v}$, ninhydrin in $95 \%, \mathrm{v} / \mathrm{v}$, ethanol in water).

A culture of Actinomyces propionicus 699 has been deposited in the American Type Culture Collection, 2112 M Street, N.W., Washington, D.C., under the number ATCC 14157.

\section{RESULTS}

As a result of preliminary fermentation studies, it became evident that Actinomyces propionicus fermented glucose in a manner typical of many species of Propionibacterium. Moreover, certain morphological and physiological characteristics 
common to the propionibacteria beame apparent. Although a brief description of the morphological and physiologizal characters of $A$. propionicus was presented previously (Pine \& Hardin, 1959), it subsequently became necessary to extend these studies and to compare the organi sm directly to known species of Actinomyces and Propionibacterium.

\section{Ce!lular morphology}

As shown in Pl. 1, fig. 1, Actinomyces propionicus formed branched mycelia typical of other members of the genus (Howell et al. 1959; Pine, Howell \& Watson, 1960). However, when the organism was grown in 11 . volumetric flasks under $\mathrm{Na}_{2} \mathrm{CO}_{3}+$ pyrogallol seals to prejare organisms for enzymic studies, a marked change in morphology occurred. For reasons which are not known, A. propionicus changed under these conditions from a short branching rod in the initial stages of growth to a long thread-like eleınent which tangled to form a cotton-like mass (Pl. 1, fig. 2). As growth progressed occasional bulbous ends were observed on some cells. In sugar fermentation tests the sugar fermented greatly influenced the morphology. After 10-14 days of incubation in glucose fermentation tubes, forms identical with those of Propionibacterium pentosaceum were observed (Pl. 1, fig. 3). Here the individual cells in a hyphal element swelled with apparent spheroplast formation. With raffinose as a sulsstrate virtually all cells rounded and swelled to form solid masses of spherical cells (Pl. 1, fig. 4). Although the number of spherical cells or hyphal-like threads which were formed varied from one substrate to another, it apparently was not directly related to the amount of growth or acid produced on any given substrate. While furthe" studies were necessary to determine what factors influenced the morphology of the organism, the morphological similarity of $A$. propionicus to certain of the propionic acid bacteria as originally described by Van Niel (1938) and by Hitchner (1932, 1934) was quite obvious. However, it may be pointed out that spherules such as those shown in Pl. 1, fig. 4, were much larger than any observed with propionibacteria. In addition, they were rigid structures resistant to the osmotic effects of distilled water or $20 \%(w / v)$ sucrose.

\section{Colony morphology}

Of the taxonomic criteria useci in the identification of species of Actinomyces, the morphology of the micro-colony is of paramount importance (Wright, 1905; Emmons, 1935; Howell et al. 1959; Pine, Howell \& Watson, 1960). Consequently, the colony morphology of Actinomyces propionicus was compared to that of Propionibacterium pentosaceum and $\boldsymbol{P}$. arabinosum (PI. 2, figs. 6, 7, 8, 9). Under low power the mycelial nature of $A$. propionicus was readily apparent, while the colony of $\boldsymbol{P}$. arabinosum was round with an unbroken periphery. Under high power, the colony of $A$. propionicus was definitely mycelial with long hyphal elements which branched repeatedly (Pl. 2, fig. 8). Under the same conditions colonies of $P$. arabinosum and $\boldsymbol{P}$. pentosaceum appeared to be mycelial although the hyphal elements were short and branching was not app arent (Pl. 2, fig. 9). Moreover, when a coverslip was placed over these colonies, they immediately disintegrated to form a freeflowing mass of individual cells having no semblance of colonial structure. On the other hand, A. propionicus tenaciously maintained its intact mycelial structure 
under these conditions. These characteristics indicated that while $A$. propionicus produced definite mycelial colonies, cells of the propionic acid bacteria were very loosely connected and did not form a true mycelium.

\section{Relative pathogenicity}

To the authors' knowledge there have been no experimental pathogenicity studies conducted with species of Propionibacterium. Consequently, comparative pathogenicity studies were made with species of Propionibacterium and Actinomyces. The results of animal inoculations with Actinomyces propionicus strongly indicated that it was no less pathogenic than any of the other species of Actinomyces tested (Table 1). The results given in Table 1 suggested, and this was supported by several additional experiments, that $A$. propionicus was slightly more pathogenic than the other strains of Actinomyces tested. On the other hand, failure to observe typical mycelial elements or any Gram-positive organisms in the lesions of animals inoculated with species of Propionibacterium, and the failure to isolate these organisms, showed that the propionibacteria were non-pathogenic. The fact that spontaneous infections in animals or man due to propionibacteria have not been reported ('Topley \& Wilson, 1957) support these observations. From the appearance of $A$. propionicus in animal lesions (Pl. 1, fig. 5) there was no doubt that it was similar morphologically to other species of Actinomyces in clinical material although it has often shown a greater propensity for being thread-like (Pine \& Hardin, 1959).

\section{Sugar fermentations}

The results of the utilization of various substrates for growth and acid production by Actinomyces propionicus and related organisms are presented in Table 2. The organism was found to follow the same general pattern of other Actinomyces in these respects. While there were other major differences between the anaerobic actinomycetes and members of the genus Propionibacterium, the complete inability of Actinomyces species to ferment and utilize glycerol for growth and acid production was the most pronounced (Howell et al. 1959; Pine, Howell \& Watson, 1960). All species of Propionibacterium ferment glycerol and lactate with the formation of acid (Bergey's Manual, 1957); A. propionicus could not use these substrates for growth in many repeated experiments. In its fermentation of sugars, A. propionicus was similar to $A$. naeslundii for it fermented raffinose but failed to ferment xylose (Howell et al. 1959). The ability to ferment mannitol was not shown by strains of $A$. naeslundii whereas mannitol always supported good growth of $A$. propionicus although acid production was variable.

\section{Physiological characteristics}

The compared physiological characteristics of the Actinomyces and Propionibacterium spp. are recorded in Table 3 . Colonies of $A$. propionicus had a dull orange colour when grown on the surface of aerobic or anaerobic tubes, whereas all other species of Actinomyces remained white. A. propionicus also produced large amounts of $\mathrm{H}_{2} \mathrm{~S}$; it was similar to the facultative anaerobe, $A$. naeslundii, in that both reduced nitrate to nitrite. A. propionicus was consistently catalase negative. On the other hand, the propionic acid bacteria were catalase positive as previously described (Bergey's Manual, 1957; Van Niel, 1928). 
Table 1. Comparative patiogenicity of species of Actinomyces and Propionibacterium

\begin{tabular}{|c|c|c|c|c|c|c|c|}
\hline Organism & $\begin{array}{l}\text { Size of } \\
\text { inoculum } \\
\text { acked cells } \\
\text { ml./mouse }\end{array}$ & $\begin{array}{l}\text { Mice } \\
\text { incu- } \\
\text { bated } \\
\text { (days) }\end{array}$ & $\begin{array}{l}\text { Wice } \\
\text { inocu- } \\
\text { lated } \\
\text { (r.o.) }\end{array}$ & $\begin{array}{l}\text { Mice } \\
\text { having } \\
\text { absces- } \\
\text { ses } \\
\text { (no.) }\end{array}$ & $\begin{array}{l}\text { Description of } \\
\text { infections* }\end{array}$ & $\begin{array}{l}\text { ramt } \\
\text { fila- } \\
\text { nents } \\
\text { o. of } \\
\text { mice }\end{array}$ & $\begin{array}{l}\text { Positive } \\
\text { isola- } \\
\text { tion } \\
\text { no. of } \\
\text { micef }\end{array}$ \\
\hline \multirow[t]{2}{*}{$\begin{array}{l}\text { Actinomyces } \\
\text { propionicus } 699\end{array}$} & 0.05 & 18 & 5 & 5 & $\begin{array}{l}\text { All mice showed multiple } \\
\text { lesions on stomach, kid- } \\
\text { ney, intestinal tract, and/ } \\
\text { or liver. One mouse had } \\
2 \mathrm{~cm} \text {. encapsulated ab- } \\
\text { scess on lower peritoneal } \\
\text { wall with numerous lesions } \\
\text { on dorsal part of liver }\end{array}$ & 5 & n.d. \\
\hline & 0.05 & 33 & 3 & 3 & $\begin{array}{l}\text { One mouse with massive in- } \\
\text { testinal abscess adherent } \\
\text { to spleen, multiple lesions } \\
\text { throughout. Second mouse } \\
\text { with two large abscesses, } \\
\text { third with single small } \\
\text { abscess on lower intestine }\end{array}$ & 3 & n.d. \\
\hline A. naeslundii 279 & 0.05 & 18 & 6 & 3 & $\begin{array}{l}\text { Two mice each with en- } \\
\text { capsulated abscess dia- } \\
\text { meter greater than } 2 \mathrm{~cm} \text {., } \\
\text { one on intestine, one on liver. } \\
\text { Multiple small abscesses } \\
\text { in addition. Third mouse } \\
\text { with large intestinal ab- } \\
\text { scess and small lesions on } \\
\text { liver and mesentery }\end{array}$ & r. & n.d. \\
\hline A. bovis P1S & 0.05 & 32 & 6 & 1 & $\begin{array}{l}\text { Small lesions adherent to } \\
\text { intestinal wall }\end{array}$ & 1 & n.d. \\
\hline \multirow[t]{2}{*}{$\begin{array}{l}\text { A. propionicus } \\
699\end{array}$} & 0.02 & 25 & 4 & 4 & $\begin{array}{l}\text { Small abscesses at point of } \\
\text { inoculation and on liver }\end{array}$ & 4 & 4 \\
\hline & $0 \cdot 02$ & 32 & 4 & 4 & $\begin{array}{l}\text { As above but two mice each } \\
\text { with single encapsulated } \\
\text { lesion } 0 \cdot 5-0 \cdot 7 \text { cm. in dia- } \\
\text { meter. One in liver, one } \\
\text { on the peritoneal wall }\end{array}$ & 4 & 4 \\
\hline \multirow[t]{2}{*}{ A. naeslundii 279} & $0 \cdot 02$ & 25 & 5 & 2 & $\begin{array}{l}\text { One with two small lesions } \\
\text { on peritoneal wall, one } \\
\text { with single lesion at point } \\
\text { of inoculation }\end{array}$ & 2 & n.d. \\
\hline & 0.02 & 32 & 5 & $\mathbf{5}$ & $\begin{array}{l}\text { Small lesions on peritoneal } \\
\text { cavity or at point of in- } \\
\text { oculation }\end{array}$ & 5 & 5 \\
\hline \multirow[t]{2}{*}{ A. israelii 895} & $0 \cdot 02$ & 25 & 4 & 3 & $\begin{array}{l}\text { One mouse with large en- } \\
\text { capsulated abscess at- } \\
\text { tached to liver and } \\
\text { stomach. Second with } \\
\text { multiple lesions through- } \\
\text { out abdominal cavity. } \\
\text { Third with three small } \\
\text { lesions on liver and one on } \\
\text { kidney }\end{array}$ & 4 & n.d. \\
\hline & $0 \cdot 02$ & 32 & 3 & $\mathbf{0}$ & No infections & $\mathbf{0}$ & n.d. \\
\hline $\begin{array}{l}\text { Propionibacterium } \\
\text { arabinosum } \\
\text { ATCC } 4965\end{array}$ & $0 \cdot 02$ & 21 & 7 & 4 & $\begin{array}{l}\text { One mouse with multiple } \\
\text { lesions on liver, three mice } \\
\text { with single small lesion at } \\
\text { point of inoculation }\end{array}$ & 0 & 0 \\
\hline $\begin{array}{l}\text { Propionibacterium } \\
\text { pentosaceum } \\
\text { ATCC } 4875\end{array}$ & $0 \cdot 02$ & 21 & 6 & 3 & $\begin{array}{l}\text { One mouse with multiple } \\
\text { lesions on liver, two mice } \\
\text { with single lesion at in- } \\
\text { oculation site }\end{array}$ & 0 & 0 \\
\hline
\end{tabular}

* Pus from the largest and most developed lesions was taken from infected mice and mounted in $10 \%(\mathrm{w} / \mathrm{v}) \mathrm{KOH}$ for microscopic examination. Although in some cases mycelial clumps were observed, typical sulphur granules wer? not seen in any of the preparations.

$\dagger$ n.d. = Quantity not determined. 
Table 2. Comparison of the growth and fermentative ability of Actinomyces propionicus with other Actinomyces and Propionibacterium spp.

$+=$ Acid and no gas (bromcresol purple indicator). Relative growth expressed in units ranging from a minimum $=1$ to a maximum $=5$. Duplicate tubes containing $5 \mathrm{ml}$. were inoculated with 1 drop of an homogenized $48-72 \mathrm{hr}$. culture and incubated under pyrogallol $+\mathrm{Na}_{2} \mathrm{CO}_{3}$ seal for 7-10 days at $37^{\circ}$. Basal medium was the Casitone medium with $1.0 \%(\mathrm{w} / \mathrm{v})$ substrate. Strain numbers are indicated below the name of each species.

\begin{tabular}{|c|c|c|c|c|c|c|c|c|c|c|c|c|}
\hline \multirow[b]{3}{*}{ Substrate } & \multicolumn{12}{|c|}{ Organism } \\
\hline & \multicolumn{2}{|c|}{$\begin{array}{c}A \\
\text { propionicus } \\
(699)\end{array}$} & \multicolumn{2}{|c|}{$\begin{array}{c}\text { A. } \\
\text { israelii } \\
(\mathbf{8 9 5 )}\end{array}$} & \multicolumn{2}{|c|}{$\begin{array}{c}\text { A. } \\
\text { bovis } \\
\text { (P1S) }\end{array}$} & \multicolumn{2}{|c|}{$\begin{array}{c}\text { A. } \\
\text { naeslundii } \\
(279)\end{array}$} & \multicolumn{2}{|c|}{\begin{tabular}{c}
\multicolumn{1}{c}{. } \\
arabinosum \\
(ATCC 4965)
\end{tabular}} & \multicolumn{2}{|c|}{$\begin{array}{c}P . \\
\text { pentosaceum } \\
(\text { ATCC 4875) }\end{array}$} \\
\hline & A.* & $\mathbf{G \dagger}$ & A. & G. & A. & G. & A. & G. & A. & G. & A. & G. \\
\hline Ylucose &,++ & 5,5 &,++ & 5,5 &,++ & 5,5 &,++ & 5,5 &,++ & $\mathbf{5}, \mathbf{5}$ &,++ & 5,5 \\
\hline ructose &,++ & 5,5 &,++ & 5,5 &,++ & 5,5 &,++ & 5,5 &,++ & 5,5 &,++ & 5,5 \\
\hline Mannose &,++ & 5,5 & n.d.\$ & n.d. & n.d. & n.d. & n.d. & n.d. &,++ & 5,5 &,++ & 4,4 \\
\hline Galactose &,++ & 3,3 &, \pm+ & 5,5 &,++ & 5,5 &,++ & 5,5 &,++ & 4,4 &,++ & 5,5 \\
\hline Lactose &,++ & 5,5 &,++ & 3,3 &,++ & 5,5 &,++ & 5,5 &,++ & 4,4 &,++ & 5,5 \\
\hline Maltose &,+ \pm & 5,5 &, \pm+ & 5,5 &,++ & 5,5 &, \pm+ & 5,5 &,++ & 4,4 &,++ & 4,4 \\
\hline Mannitol &,+- & 5,5 &, \pm \pm & 4,4 &,-- & 1,1 &,-- & 5,5 &,++ & 4,4 &,++ & 4,4 \\
\hline Suc &, \pm \pm & 5,5 &,++ & 5,5 &,++ & 5,5 &,++ & 5,5 &,++ & 4,4 &,++ & 4,4 \\
\hline Xylose &,-- & 1,1 &,++ & 5,5 &,-- & 1,1 &,-- & 3,3 &,-- & 2,2 &,++ & 4,4 \\
\hline Raffinose &, \pm \pm & 5,5 &,++ & 5,5 &,-- & 1,1 &,++ & 5,5 &,-- & 1,1 &,++ & 4. 4 \\
\hline Arabinose &,++ & 5,5 &,-- & 1,1 &,-- & 1,1 &,-- & 1,1 &,-- & 1,1 &,++ & 4,4 \\
\hline Ribose &, \pm \pm & 3,3 &,++ & 5,5 &,-- & 1,1 &,-- & 1,1 &,++ & 4,4 &,++ & 4,4 \\
\hline Rhamnose &,-- & 3,3 &,-- & 3,3 &, \pm \pm & 5,5 &,-- & 1,1 &,+ \pm & 3,3 &,++ & 3,3 \\
\hline Salicin &,-- & 2,2 &,++ & 5,5 &, \pm \pm & 1,1 &, \pm \pm & 5,5 &, \pm \pm & 3,3 &, \pm \pm & 3,3 \\
\hline Starch &, \pm \pm & 5,5 &, \pm \pm & 5,5 & $+\overline{+}$ & 5,5 &, \pm \pm & 5,5 & $-\overline{-}$ & 2,2 & $\overrightarrow{ \pm}, \overrightarrow{ \pm}$ & 4,4 \\
\hline Glyc &,-- & 1,1 & n.d. & n.d. & n.d. & n.d. & n.d. & n.d. &,-- & 1,1 &,-- & 2,2 \\
\hline acid &,-- & 1,1 &,-- & 1,1 &,-- & 1,1 &,-- & 1,1 &,++ & 5,5 &,++ & 5,5 \\
\hline Glycerol &,-- & 1,1 &,-- & 1,1 &,-- & 1,1 &,-- & 1,1 &,++ & 5,5 & & 5,5 \\
\hline Cellulose &,-- & 1,1 & n.d. & n.d. & n.d. & n.d. & n.d. & n.d. & n.d. & n.d. & n.d. & n.d. \\
\hline
\end{tabular}

$* \mathbf{A}=$ Acid production. $\dagger$ G. $=$ Growth. $\ddagger$ n.d. $=$ quantity not determined.

\section{Carbon dioxide requirement for anaerobic and aerobic growth}

All species of Actinomyces have been shown to require $\mathrm{CO}_{2}$ for maximum anaerobic growth, while $A$. naeslundii, a facultative anaerobe, manifests a similar requirement aerobically (Pine \& Howell, 1956; Howell et al. 1959). Consequently, the $\mathrm{CO}_{2}$ requirement for $A$. propionicus was investigated, both anaerobically and aerobically. As seen in Table 4, this organism was similar to $A$. naeslundii in that it grew well aerobically although anaerobic growth was induced by a smaller inoculum than that required for aerobic growth. In contrast to $\boldsymbol{A}$. naeslundii (Howell et al. 1959) $\mathrm{CO}_{2}$ had no stimulating effect on aerobic growth of $A$.propionicus. A comparison of the growth curves of $A$. naeslundii grown aerobically in the presence and absence of added $\mathrm{CO}_{2}$ with those of $A$. propionicus showed conclusively that $A$. propionicus did not have the $\mathrm{CO}_{2}$ requirement for aerobic growth so consistently demonstrated for $A$. naeslundii (Fig. 1). Similarly, fermentations carried out under a $\mathrm{NaOH}$ + pyrogallol seal revealed that $A$. propionicus did not require $\mathrm{CO}_{2}$ for anaerobic growth (Table 5). 
Table 3. Physiological characteristics of Actinomyces propionicus and Actinomyces and Propionibacterium spp.

Physiological tests were carried (ut as described previously (Pine \& Howell, 1956). With the exception of litmus milk, basal medium was the Casitone medium with $1.0 \%$ $(w / v)$ glucose. Conditions of growth as given in legend to Table 2.

\begin{tabular}{|c|c|c|c|c|c|c|}
\hline Character & $\begin{array}{c}A . \\
\text { propionicus } \\
(699)\end{array}$ & $\begin{array}{c}A . \\
\text { israelii } \\
(895)\end{array}$ & $\begin{array}{c}\text { A. } \\
\text { bovis } \\
\text { (P1S) }\end{array}$ & $\begin{array}{c}A . \\
\text { naeslundii } \\
(\mathbf{2 7 9 )}\end{array}$ & $\begin{array}{c}P . \\
\text { arabinosum } \\
(4965)\end{array}$ & $\begin{array}{c}P . \\
\text { pentosaceum } \\
(4875)\end{array}$ \\
\hline Catalase & -* & - & - & - & + & $\stackrel{+}{+}$ \\
\hline $\begin{array}{l}\text { Colour } \\
\text { Gelatin } \\
\text { liquefaction }\end{array}$ & $\begin{array}{c}\text { Dull orange } \\
-\end{array}$ & $\begin{array}{c}\text { White } \\
-\end{array}$ & White & $\begin{array}{c}\text { White } \\
-\end{array}$ & Orange-yellow & $\begin{array}{c}\text { Cream } \\
-\end{array}$ \\
\hline $\begin{array}{l}\text { Starch } \\
\text { hydrolysis }\end{array}$ & - & - & + & - & - & - \\
\hline $\begin{array}{l}\text { Indole } \\
\text { production }\end{array}$ & + & + & + & + & - & - \\
\hline $\begin{array}{l}\text { Nitrate reduced } \\
\text { to nitrite }\end{array}$ & + & - & - & + & + & - \\
\hline $\begin{array}{l}\text { Acetoin pro- } \\
\text { duction }\end{array}$ & - & - & - & - & - & - \\
\hline $\mathrm{H}_{2} \mathrm{~S}$ formation & + & - & - & - & \pm & - \\
\hline
\end{tabular}

* Catalase was negative whether the organism was grown aerobically or anaerobically in the presence or absence of added haemin.

Table 4. Effect of inoculun; size on anaerobic and aerobic growth of Actincmyces propionicus

A $48 \mathrm{hr}$. culture of A. propionicus was homogenized and diluted with sterile distilled water to an optical density $=0.5$. This suspension was serially diluted with water as indicated. Duplicate tubes containingr $5 \mathrm{ml}$. of Casitone medium with $0.5 \%(\mathrm{w} / \mathrm{v})$ glucose were inoculated with 1 drop of each dilution and incubated for $84 \mathrm{hr}$. at $37^{\circ}$. Aerobic cultures were grown on a rotary shaker. Relative growth expressed for duplicate tubes in units ranging from a minimum $=1$ to a maximum $=5 ;-$ signifies no growth.

Dilution used for inoculum

Growth conditions

Anaerobic:

$\mathrm{Na}_{2} \mathrm{CO}_{3}+$ pyrogallol seal Aerobic:

$\mathrm{Na}_{2} \mathrm{CO}_{3}+\mathrm{KH}_{2} \mathrm{PO}_{4}$ seal

Aerobic: no seal

\begin{tabular}{ccccccc}
$10^{-1} \quad 10^{-2}$ & $10^{-3}$ & $10^{-4}$ & $\begin{array}{c}10^{-5} \\
\text { Relative growth }\end{array}$ & $10^{-6}$ & $10^{-8}$ & $10^{-9}$ \\
\hline
\end{tabular}

$\begin{array}{lllllllll}5,5 & 5,5 & 4,4 & 4,4 & 3,3 & 2,1 & 2,1 & 2,1 & 2,1\end{array}$

$5,5 \quad 5,5 \quad 3,2 \quad 5,2 \quad 1,-\quad-,,-\quad-,-\quad-,-\quad-,-$

$5,5 \quad 5,5 \quad 2,2 \quad 1,1 \quad-,-\quad-,-\quad-,--,-\quad-,-$

Comparative growth of species of Actinomyces

Figure 2 shows the comparative gyowth curves of species of Actinomyces. Anaerobically the rate of growth of $A$. propionicus was not usually as great as that of $A$. naeslundii and was usually less than that of $A$. bovis or a granular strain of A. israelii. However, as shown in Fig. 2 the yields of A. propionicus grown anaerobically were comparable to those of $A$. naeslundii and much greater than those of $A$. israelii and $A$. bovis. Generally, species of Actinomyces utilize only 25-30 $\mu$ mole glucose/ml. medium (Pine \& How ll, 1956). This has been shown to be due to sensitivity of these organisms to the acid formed; greater glucose utilization with 
increased yields of growth occurred in an adequately buffered medium (Buchanan $\&$ Pine, unpublished results). However, A. propionicus utilized only $16 \mu$ mole glucose $/ \mathrm{ml}$. in Casitone medium, yet the growth yields as judged by optical density measurements were greater than those observed for the other species (Fig. 2). This ability of $A$. propionicus to form more organisms from less glucose would appear to be related to a more efficient pathway of glucose dissimilation (Bauchop $\&$ Elsden, 1960). Usually growth yields of $A$. naeslundii doubled in the presence of oxygen (Pine \& Howell, 1956; Buchanan \& Pine, unpublished results). However, without changing the medium, growth of $A$. propionicus in air did not increase significantly (Figs. 1, 2), although all the glucose $(27 \mu \mathrm{mole} / \mathrm{ml}$.) was utilized (Table 5). The reason for this is unknown at present; it may be due to the limitation of growth factors in the medium.

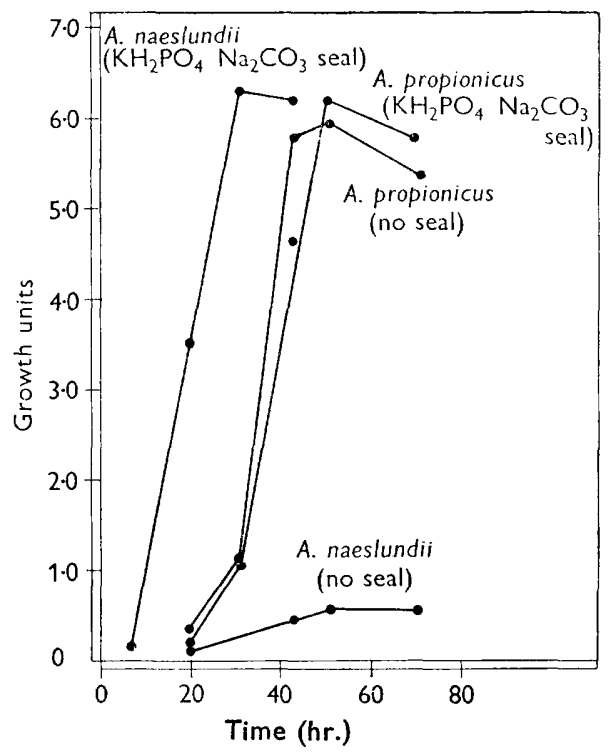

Fig. 1

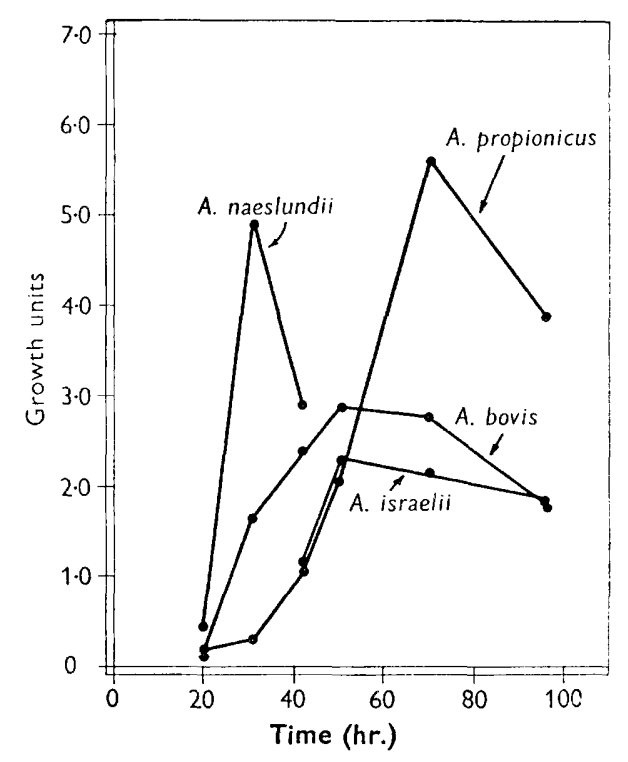

Fig. 2

Fig. 1. Comparative aerobic growth of Actinomyces propionicus and A. naeslundii with and without added $\mathrm{CO}_{2}$.

Fig. 2. Comparative anaerobic growth of species of Actinomyces.

\section{Fermentation balances}

The results of the glucose fermentations of Actinomyces propionicus and related organisms are given in Table 5. Anaerobically, in the presence or absence of added $\mathrm{CO}_{2}, A$. propionicus produced principally $\mathrm{CO}_{2}$, acetic and propionic acids, with a ratio of products that was typical of many strains of Propionibacterium. However, the reported utilization of glucose by Propionibacterium spp. was much greater than that observed for A. propionicus (Wood \& Werkman, 1936). From 70 to $80 \%$ of the total carbon utilized could be accounted for by these products. While their concentrations were quite small, lactate and succinate were definitely produced under these conditions, although the amounts of lactate produced varied. After consideration of the data of Wood \& Werkman (1936) and Wood, Stone \& Werkman 
(1937) it was concluded that there was no significant qualitative or quantitative difference between glucose fermentations of $A$. propionicus and species of Propionibacterium other than the total am.ount of glucose fermented.

Aerobically in the absence of added $\mathrm{CO}_{2}$, Actinomyces propionicus fermented glucose to yield stoichiometric amounts of acetic acid and $\mathrm{CO}_{2}$. While there was a small percentage of carbon which remained unaccounted for, this was not present in the ether-extractable non-volatile fraction. Absence of radioactivity in any remaining fraction other than whole cells indicated that no other products were formed in significant amounts.

Table 5. Glucose fermentation balances for Actinomyces propionicus and related organisms

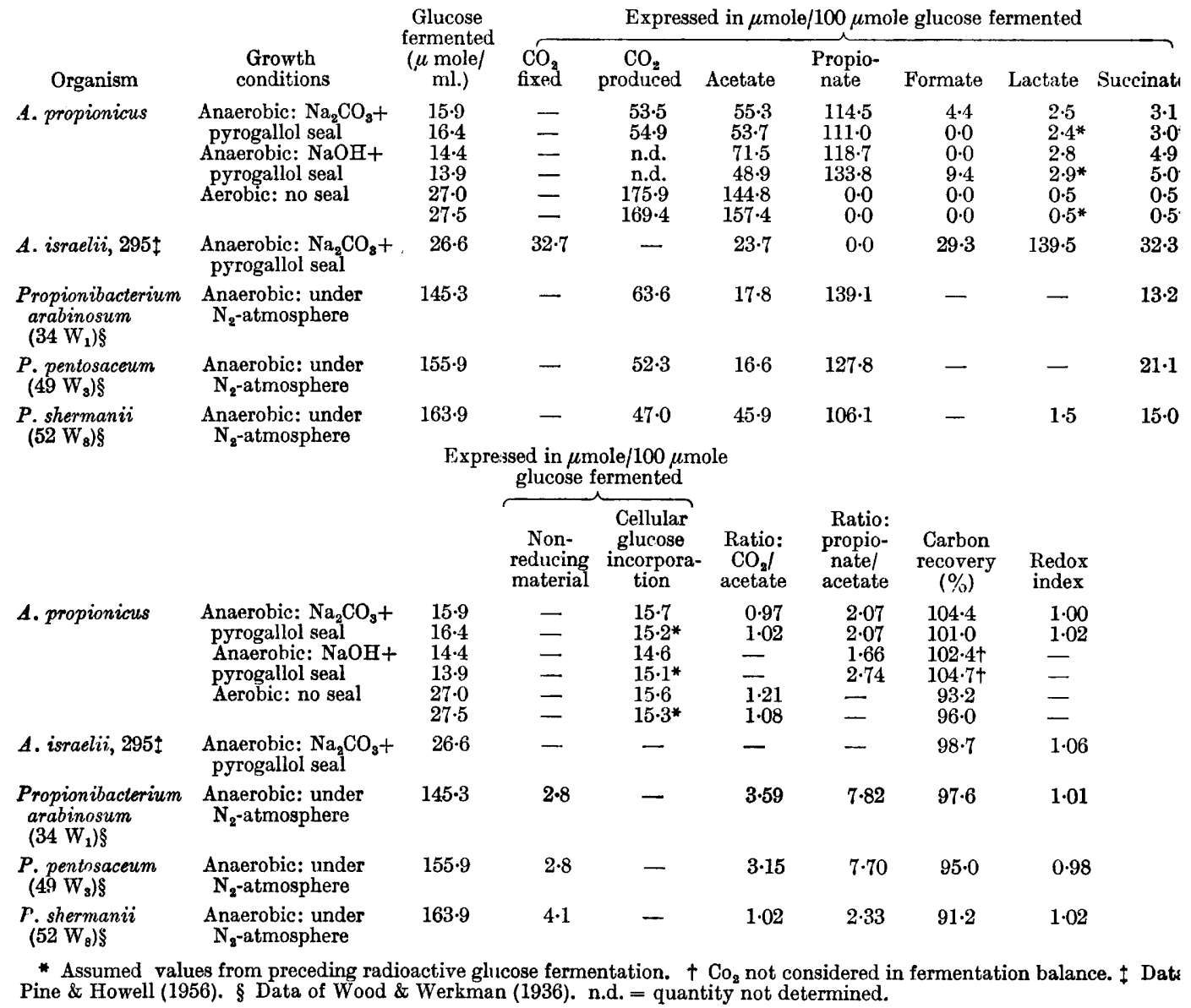

\section{Optical rotation of lactic acid}

Although the amount of lactic acid produced by Actinomyces propionicus varied, it was generally quite small in large fermentations. From 61 . of fermentation liquor about $6 \mathrm{~g}$. zinc lactate were obtained, of specific rotation $+0 \cdot 10$. Because of relations to be discussed subsequently, the lactic acid formed by Bacterionema 


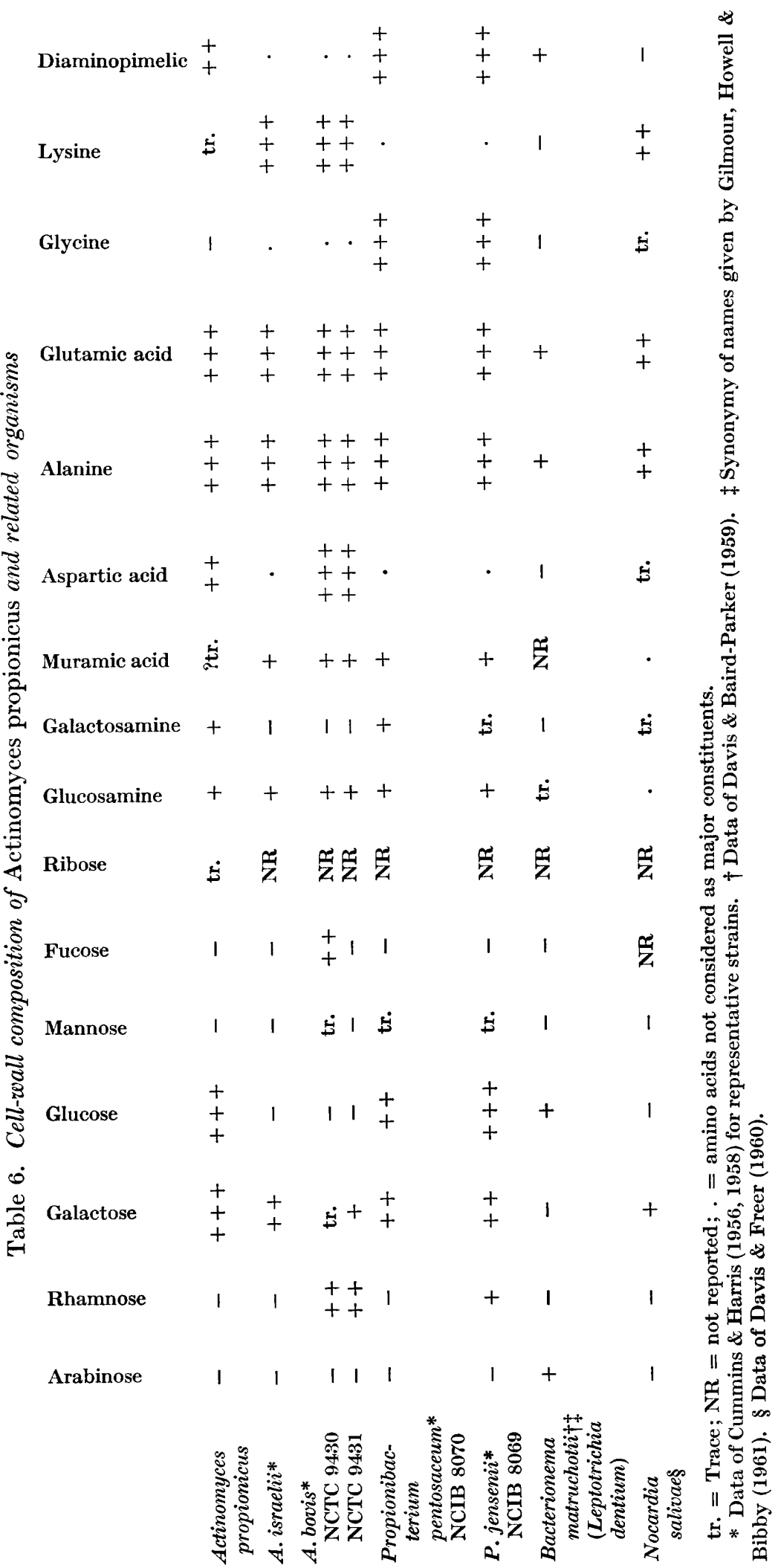


matruchotii (Leptotrichia dentium); Baird-Parker \& Davis, 1958 (Gilmour, Howell \& Bibby, 1961) was converted to the zinc salt and optically assayed as described for A. propionicus. A specific rotation of -0.63 was found. Since the zinc salt of the pure optically active isomer has a specific rotation of + or $-8 \cdot 25$ (Pederson, Peterson \& Fred, 1926) and because of the low solubility of the zinc lactates of the two organisms tested, it was corcluded that both B. matruchotii and A. propionicus formed DL-lactic acid.

\section{Cell-roall analysis}

Cummins \& Harris (1958, 1959), Davis \& Baird-Parker (1959) and Davis \& Freer (1960) have shown cell-wall composition to be a general taxonomical character relevant to the classification of Actinomycetales. Consequently, cell walls of Actinomyces propionicus were isclated and analysed. The results of this analysis and those of several related organisms as reported by other workers are given in Table 6 . Alanine, glutamic, aspartic, anc diaminopimelic acids were the major amino acid components of the $A$. propionicus cell-wall hydrolysate, while there was a small but definite amount of lysine. There appeared to be a trace of muramic acid as suggested by the colour formed with ninl ydrin and its position on the paper, but this was not further identified. Galactose and glucose and glucosamine and galactosamine represented the major sugar and amino sugar constituents, respectively. No attempt was made to determine the stereoisomeric form of the diaminopimelic acid.

\section{DISCUSSION}

From the results of experiments comparing pathogenicity of Propionibacterium spp. and Actinomyces spp., it i:; obvious that Actinomyces propionicus is readily classified in the genus Actinomyces, although pathogenicity is not usually a taxonomic characteristic used to separate genera. Stanier \& Van Niel (1941) and Howell et al. (1959) emphasized morphology as the primary diagnostic character pertaining to the classification of members of the Actinomycetales. Primarily on the basis of its colony morphology and its morphological appearance in animals, A. propionicus was initially classified as a strain of $A$. israelii (Pine \& Hardin, 1959). In the original spontaneous infection and in inoc ulated animals the long branching mycelial threads were typical of strains of $A$. bov:s, $A$. israelii and $A$. naeslundii.

On the basis of cellular morplology in vitro, there is little to distinguish Actinomyces propionicus from Propionibacterium arabinosum or $\boldsymbol{P}$. pentosaceum, although during the logarithmic growth phase there is a much greater tendency for $A$. propionicus to form true branching rods and hyphal elements. Subsequent to the stationary phase of growth or derendent upon cultural conditions and media, the propionibacteria form spherical cells which may be normal or greatly enlarged in diameter. In this respect the cel s of A. propionicus may be identical with those of $\boldsymbol{P}$. arabinosum (Skerman, 1959), although the cells of $A$. propionicus continue to enlarge under certain conditions of substrate and age to form huge spheres not unlike the cystites of Arthrobacter species (Chaplin, 1957; Skerman, 1959). Although there have been no direct experiment; to determine the nature of these morphological changes, the impression gained from general observation strongly suggests that these coccoidal or swollen forms are a result of abnormal cell-wall formation and do not 
constitute a normal phase of the organism's growth. Similar types of cells have been observed in cultures of $A$. bovis (Pine, Howell \& Watson, 1960) although these lacked the rigidity of structure observed in cells of $A$. propionicus.

Perhaps one of the strongest diagnostic characteristics identifying the anaerobic actinomycetes infecting man is the formation within a few days of small delicate mycelial colonies on the agar surface. In this regard, Actinomyces propionicus formed a colony typical of that formed by strains of $A$. israelii, whereas such a colonial structure was completely absent in the colonies of Propionibacterium arabinosum and $\boldsymbol{P}$. pentosaceum. However, similar to the colonies of $\boldsymbol{P}$. arabinosum (Bergey's Manual, 1957), the colonies of $A$. propionicus grown aerobically or anaerobically on the surface of agar media gradually assumed a dull orange colour within several weeks while all other strains of Actinomyces spp. remained white or cream.

In its physiological and fermentative aspects Actinomyces propionicus does not show distinctive characters of its own but combines several of the identifying characteristics of the genera Actinomyces and Propionibacterium. Like all members of the genus Actinomyces (Pine \& Howell, 1956; Howell et al. 1959; Pine, Howell \& Watson, 1960) A. propionicus does not ferment lactic acid or glycerol, whereas these substrates are fermented by all Propionibacterium spp. (Bergey's Manual, 1957). Like most strains of $A$. naeslundii (Howell et al. 1959), A. propionicus ferments raffinose but does not ferment xylose or mannitol, although growth of $A$. propionicus on mannitol is invariably good and substantial acid formation is occasionally observed. Like all strains of $\boldsymbol{A}$. naeslundii tested, $\boldsymbol{A}$. propionicus reduces nitrates to nitrites.

Species of Actinomyces are generally recognized as being catalase negative (Suter, 1956; Hazen \& Little, 1958; Pine \& Howell, 1956; King \& Meyer, 1957; Howell et al. 1959; Pine, Howell \& Watson, 1960). Similarly Actinomyces propionicus was found to be catalase negative. Since catalase may be an inducible enzyme (Clayton, 1960) or be dependent upon the presence of essential factors (Biberstein \& Gills, 1961) many attempts were made to demonstrate the formation of catalase by $\boldsymbol{A}$. propionicus grown anaerobically or aerobically in the presence and absence of added haemin; these attempts failed and catalase formation was not demonstrated. On the other hand, catalase activity of Propionibacterium arabinosum and $\boldsymbol{P}$. pentosaceum has been described as being extremely limited (Bergey's manual, 1957). Although this was true of $P$. arabinosum when it was received, the initial catalase activity of $\boldsymbol{P}$. pentosaceum was high. However, with further culturing on the Casitone medium, the catalase activity of $\boldsymbol{P}$. arabinosum also became strongly positive.

All strains of Actinomyces studied previously required substrate amounts of $\mathrm{CO}_{2}$ to ferment glucose, forming formic, acetic, lactic and succinic acids (Pine \& Howell, 1956; Pine, Howell \& Watson, 1960). Unlike the Actinomyces, but similar to the glucose fermentations of species of Propionibacterium, Actinomyces propionicus fermented glucose with the formation of $\mathrm{CO}_{2}$, acetic and propionic acids, and small amounts of formic, lactic and succinic acids. Thus unlike the Actinomyces, $\mathrm{CO}_{2}$ was not required for anaerobic growth but was a major product of fermentation. Like the fermentations of Propionibacterium (Wood et al. 1937) significant amounts of lactic acid were not consistently formed, whereas this is a major product of all Actinomyces fermentations. Like A. naeslundii (Buchanan \& Pine, unpublished 
results) and $P$. arabinosum (Ichikawa, 1957), A. propionicus was facultative and fermented glucose in the presence of oxygen to form stoichiometric amounts of $\mathrm{CO}_{2}$ and acetic acid. However, unlike $A$. naeslundii, A. propionicus did not require $\mathrm{CO}_{2}$ to grow and ferment glucost in the presence of oxygen.

Table 7. A suggested phylog'enetic progression in the order Actinomyctales

\section{Organism}

Lactobacillus bifidus

Actinomyces israelii

A. naeslundii

A. propionicus

X (Propionibacterium) species

Y (Corynebacterium) species

Bacterionema matruchotii (Leptotrichia dentium)

Nocardia and Streptomyces species

\section{Characters}

Branchir g cells, no true mycelium. Anaerobic, catalase negative. Ferments glucose with formation of large amounts of lactic $(\mathbf{L}+)$ and ace tic acid, traces of formic and succinic also formed. Lysine in cell vall. Parasitic (Norris, Flanders, Tomarelli \& György, 1950; Frank is Skinner, 1954; Pine \& Howell, 1956; Cummins, Glendenning \& Harris, 1957).

Branching cells, true mycelium formed. Anaerobic, catalase negative. Fermer ts glucose and $\mathrm{CO}_{2}$ to form acetic, formic, lactic $(\mathbf{L}+)$, and succinic acids. Lysine in cell wall. Parasitic and pathogenic. (Pine \& How.ll, 1956; Cummins \& Harris, 1958).

Branching cells, true mycelium formed. Facultative, catalase negative. Ferments glucose and $\mathrm{CO}_{2}$ to form lactic $(\mathrm{L}+)$, formic, acetic and succinic acids. Aerobically, glucose is oxidized in the presence of $\mathrm{CO}_{2}$ to form $\mathrm{CO}_{2}$ and acetic acid. Lysine in cell wall. Parasitic and pathogenic (Pine \& Howell, 1956; Cummins \& Harris, 1958; Howell et al. 1959; Buchanan \& Pine, unpublished results).

Branching cells, true mycelium formed. Facultative, catalase negative. Ferments glucose to form $\mathrm{CO}_{2}$, acetic and propionic acids with small amounts of lactic (DL) and succinic acids. Aerobically, glucose is oxidized to form $\mathrm{CO}_{2}$ and acetic acid. Diaminopimelic acid in cell wall. Parasitic and pathogenic.

Branching cells, true mycelium not formed. Facultative, catalase positiv?. Ferments glucose to form $\mathrm{CO}_{2}$, acetic, succinic and propionic acids. Jactic acid fermented. Aerobically, glucose is oxidized to form $\mathrm{CO}_{2}$ ar d acetic acid. Diaminopimelic acid in cell wall. Enzymes oxidizing citric acid cyclc intermediates present. Saprophytic (Hitchner, 1934; Wood \& Werkman, 1936; Delwiche \& Carson, 1953; Ichikawa, 1957; Cummins \& Harris, 1958).

Branching cells, true mycelium not formed. Facultative to aerobic, catalase positive, cytochrome transport system present. Ferments glucose in decreased oxygen supply to form $\mathrm{CO}_{2}$, acetic, formic, lactic, succinic, and propionic acids. With adequate oxygen, these products oxidized to $\mathrm{CO}_{2}$ and $\mathrm{H}_{2} \mathrm{O}$. Diaminopimelic* acid in cell wall. Parasitic, pathogenic, saprophytic (Tasman \& Brandwijk, 1940; Pappenheimer \& Hendee, 1947; Cummins \& Harris, 1956).

Branching cells, true mycelium formed. Facultative to strict aerobes, catalase positive. Ferments glucose in decreased oxygen supply to form $\mathrm{CO}_{2}$, formic, acetic, propionic, lactic (DL) and succinic acids. With adequate oxygen, glucose and lactic acid oxidized presumably

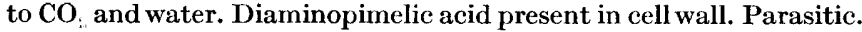
(Davi: \& Baird-Parker, 1959 ; Gilmour, 1961 ; Pine \& Howell, 1961).

Brancling cells, true mycelium formed with production of chains of endospores. Strict aerobes, glucose and various carbohydrates oxidized to $\mathrm{CO}_{2}$ and $\mathrm{H}_{2} \mathrm{O}$. Catalase positive. Diaminopimelic acid in cel wall. Saprophytic and pathogenic (Gordon \& Mihm, 1958; Gilmour, Butterworth, Noble \& Wang, 1955; Butterworth, Gilmour \& Wang, 1955; Cummins \& Harris, 1958; Moore \& Chapman, 1959).

* Of ten species of Corynebacteriun studied by Cummins \& Harris (1956), two (C. pyrogenes and C. hemolyticum) had lysine instead of diaminopimelic acid. 
Hungate (1946) described a propionic acid fermentation by the strict anaerobe Micromonospora propionici (Actinobacterium propionici, Prévot, 1957) isolated from the gut of a wood termite. Although its anaerobic fermentations were identical with those of Actinomyces propionicus and its morphology similar, it would appear that $M$. propionici is a different organism from $A$. propionicus on the basis of habitat, anaerobic requirements and use of cellulose as a substrate.

The form of lactic acid formed by a species has been used for taxonomic differentiation particularly among the members of the family Lactobacteriaceae. There has been no report on the kind of lactic acid formed by strains of Propionibacterium. However of the Actinomyces spp. studied, A. naeslundii, A. israelii, and A. bovis form $\mathrm{L}(+)$-lactic acid. On the other hand, $A$. propionicus was found to produce DL-lactic acid, as did Bacterionema matruchotii, which is a genus considered phylogenetically intermediate between Actinomyces and Nocardia (Gilmour et al. 1961; Gilmour 1961; Gilmour \& Beck, 1961; Howell \& Pine, 1961). This observation serves to relate these two species (Table 7) as does their common ability to form propionic acid (Howell \& Pine, 1961) and similar cell-wall constituents (Davis \& Baird-Parker, 1959).

Cummins \& Harris $(1956,1958)$ and Davis \& Baird-Parker (1959) have emphasized the taxonomic value of cell-wall composition to determine species and generic relationships among members of the actinomycetes. In this regard, cell walls of Actinomyces propionicus were found to contain glucose, galactose, small amounts of glucosamine and galactosamine, and aspartic and diaminopimelic acids. This composition is similar to that of species of Propionibacterium except the latter had glycine and no aspartic acid (Cummins \& Harris, 1956, 1958). The cell-wall composition of A. propionicus was essentially the same as that of Bacterionema matruchotii (Leptotrichia dentium) except the walls of the latter contained no galactose or aspartic acid. A. propionicus differed from all other members of the genus Actinomyces in the sugars found in the cell wall and in the fact that all other Actinomyces species had lysine instead of diaminopimelic acid (Cummins \& Harris, 1958, 1959). Therefore, on the basis of cell-wall composition $A$. propionicus is distinct from all related organisms.

It is apparent that the interest in Actinomyces propionicus lies in its phylogenetic relationship to other actinomycetes and to propionibacteria. Starting with the simple branching anaerobic Lactobacillus bifidus var. pennsylvanicus (Sundman, Björksten \& Gyllenberg, 1959), one may make a morphological and physiological progression to the more complex sporulating actinomycetes having an aerobic metabolism (Table 7). Table 7 shows the relationships of members of the genus Actinomyces to some other organisms which have been classified in the Actinomycetales, or which have been recognized by various investigators as being related to members of this order. So far there have been described no species forming true mycelium which might fill the gaps $\mathrm{X}$ and $\mathrm{Y}$ in Table 7 , and which might have the progressively more complicated metabolic characteristics found in the genera Propionibacterium and Corynebacterium. Although the relationships of members of these genera to members in the genus Actinomyces have long been recognized on a morphological and physiological basis (Bergey's Manual, 1934, 1939; Stanier \& Van Niel, 1941), these taxonomic schemes have been complicated by the assignment of a more complex cellular structure to Actinomyces, because of the formation 
of a true mycelium. Conseque ttly on a morphological basis, Propionibacterium and Corynebacterium have been considered to precede the more ccmplex Actinomyces (Stanier \& Van Niel, 1941; Prévot, 1957).

However, in the light of present knowledge about the physiological basis of morphology and its relationshi]) to cell-wall composition (Duguid \& Wilkinson, 1961; Glick, Sall, Zilliken \& Mudd, 1960), the formation of branching cells with true hyphal elements may be considered the result of a decrease, rather than an increase, in enzymic complexity. Formation of buds or branches due to defective cell-wall synthesis and the forraation of branched hyphae and even mycelium due to delayed cross-wall formation might represent an impaired operation of cellwall synthesizing enzymes. This functional loss need not necessarily benefit the organism nor be conducive to its survival. On the other hand, the formation of chains of catenulae (oidia) observed in strains of Nocardia or Streptomyces (Gordon \& Mihm, 1958; Moore \& Chapman, 1959) most certainly indicates a more complex morphological development pertinent to the life cycle and increased survival of the organism. From these considerations it is not unreasonable to substitute Propionibacterium for $\mathrm{X}$ in Table 7 as a metabolically more complex genus following Actinomyces (A. propionicus), and Corynebacterium for $\mathrm{Y}$ in the postulated phylogenetic progression from Lactobacillus to Streptomyces shown in Table 7. Further clarification of the taxonomic relationsh ps of these genera with more recently described genera and species such as Bacterionema matruchotii and Nocardia salivae will require additional information ak out the intermediary metabolism of these organisms and members of the genus Lictinomyces.

B.B.B. was a U.S.P.H.S. Precoctoral Fellow during this work which was supported by U.S.P.H.S. Grant E-1866 (C3) and U.S.P.H.S. Senior Research Fellowship SF-64-C 3.

\section{REFERENCES}

Baird-Parker, A. C. \& Davis, G. II. G. (1958). The morphology of Leptotrichia species. J. gen. Microbiol. 19, 446.

BaUCHOP, 'T. \& ElsDen, S. R. (1960). The growth of microorganisms in relation to their energy supply. J. gen. Microbiol. 23, 457.

Bergey's Manual of Determinative Bacteriology (1934). 4th ed. Ed. D. H. Bergey, R.S. Breed, F. M. Huntoon, B. W. Hammer, I. G. D. Murray \& F. C. Harrison. Baltimore: The Williams and Wilkins Company.

Bergey's Manual of Determinative Bacteriology (1939). 5th ed. Ed. R. S. Breed, E. G. D. Murray \& A. P. Hitchens. Baltimore: The Williams and Wilkins Company.

Bergey's Manual of Determinative Basteriology (1957). 7th ed. Ed. R. S. Breed, E. G. D. Murray \& N. R. Smith. Baltimore: The Williams and Wilkins Company.

Biberstein, E. L. \& Gills, M. (1961). Catalase activity of Haemophilus species grown with graded amounts of hemin. J. Bact. 81, 380.

Busch, H., Hurlbert, R. B. \& Potjer, V. R. (1952). An ion exchange chromatography of acids of the citric acid cycle. J. biol. Chem. 196, 717 .

Butter worth, E. M., Gilmour, C. M. \& Wang, C. H. (1955). Studies on the biochemistry of the streptomyces. II. Fixation of ${ }^{14} \mathrm{CO}_{2}$ by intact cells of Streptomyces griseus. $J$. Bact. 69, 725.

Chaplin, C. E. (1957). Life cycles in Arthrobacter pascens and Arthrobacter terregens. Canad. J. Microbiol. 3, 103.

Clayton, R. K. (1960). Protein synthesis in the induced formation of catalase in Rhodopseudomonas spheroides. J. biol. Chem. 235, 405. 
Cummins, C. S., Glendenning, O. M. \& Harris, H. (1957). Composition of the cell wall of Lactobacillus bifidus. Nature, Lond. 180, 337.

Cummins, C. S. \& Harris, H. (1956). The chemical composition of the cell wall in some gram-positive bacteria and its possible value as a taxonomic character. J. gen. Microbiol. 14, 583.

Cummins, C. S. \& Harris, H. (1958). Studies on the cell-wall composition and taxonomy of Actinomycetales and related groups. J. gen. Microbiol. 18, 173.

Cummins, C. S. \& Harris, H. (1959). Cell wall composition in strains of Actinomyces isolated from human and bovine lesions. J. gen. Microbiol. 21, ii.

Davis, G. H. G. \& BaIrd-Parker, A. C. (1959). The classification of certain filamentous bacteria with respect to their chemical composition. J. gen. Microbiol. $21,612$.

Davis, G. H. G. \& Freer, J. H. (1960). Studies upon an oral aerobic actinomycete. $J$. gen. Microbiol. 23, 163.

Delwiche, E. A. \& Carson, S. F. (1953). A citric acid cycle in Propionibacterium pentosaceum. J. Bact. 65, 318.

Duguid, J. B. \& Wilkinson, J. F. (1961). Environmentally induced changes in bacterial morphology. In Microbial Reaction to Environment. Symp. Soc. gen. Microbiol. 11, 69.

Emmons, C. W. (1935). Actinomyces and actinomycosis. Puerto Rico. J. publ. Hth, 11, 63.

FriedemanN, T. E. (1938). The identification and quantative determination of volatile alcohols and acids. J. biol. Chem. 123, 161.

Frank, H. H. \& Skinner, C. E. (1954). The relationship between Actinomyces bovis and Lactobacillus bifidus. Mycologia, 46, 728.

Grlmour, C. M., Butterworth, E. M., Noble, E. P. \& Wang, C. H. (1955). Studies on the biochemistry of the streptomyces. I. Terminal oxidative metabolism in Streptomyces griseus. J. Bact. 69, 719.

GrLmour, M. N. (1961). The classification of organisms termed Leptotrichia (Leptothrix) buccalis. II. Reproduction of Bacterionema matruchotii. Bact. Rev. 25, 142.

GrLmour, M. N. \& BEck, P. H. (1961). The classification of organisms termed Leptotrichia (Leptothrix) buccalis. III. Growth and biochemical characteristics of Bacterionema matruchotii. Bact. Rev. 25, 152.

Grlmour, M. N., Howell, A., Jun. \& BibBy, B. G. (1961). The classification of organisms termed Leptotrichia (Leptothrix) buccalis. I. Review of the literature and proposed separation into Leptotrichia buccalis (Trevison, 1879) and Bacterionema gen.nov., B. matruchotii (Méndel, 1919) comb.nov. Bact. Rev. 25, 131.

Glick, M. C., Sall, T., Zilliken, F. \& Mudd, S. (1960). Morphological changes of Lactobacillus bifidus var. pennsylvanicus produced by a cell-wall precursor. Biochim. biophys. Acta, 37, 361.

Gordon, R. E. \& Mrhm, J. M. (1958). Sporulation by two strains of Nocardia asteroides. J. Bact. 75, 239.

Hazen, E. L. \& Little, G. N. (1958). Actinomyces bovis and 'anaerobic diphtheroids': pathogenicity for hamsters and some other differentiating characteristics. J. Lab. clin. Med. 51, 968.

Hitchner, E. R. (1932). A cultural study of the propionic-acid bacteria. J. Bact. 23, 40.

Hitchner, E. R. (1934). Some physiological characteristics of the propionic acid bacteria. J. Bact. 28, 473.

Howell, A., Jun., Murphy, W. C. III, Paul, F. \& Stephan, R. M. (1959). Oral strains of Actinomyces. J. Bact. 78, 82.

Howell, A., Jun. \& Pine, L. (1956). Studies on the growth of species of Actinomyces. I. Cultivation in a synthetic medium with starch. J. Bact. 71, 47.

Howell, A., Jun. \& Prne, L. (1961). The classification of organisms termed Leptotrichia (Leptothrix) buccalis. IV. Physiological and biochemical characteristics of Bacterionema matruchotii. Bact. Rev. 25, 162.

Hungate, R. E. (1946). Studies on cellulose fermentation. II. An anaerobic cellulosedecomposing actinomycete, Micromonospora propionici, n.sp. J. Bact. 51, 51.

IChrkawa, Y. In Chem. Abstracts (1957). Propionic acid bacteria. II. Anaerobic decomposition of the substrates by Propionibacterium arabinosum. Nippon Nôgei-kagaku Kaishi, 29, 353. 
KING, S. \& MEYER, E. (1957). Metabolic and serologic differentiation of Actinomyces bovis and 'anaerobic diphtheroids'. J. Bact. 74, 234.

Moore, R. T. \& Chapman, G. B. (1959). Observations of the fine structure and modes of growth of a streptomycete. J. Bact. 78, 878 .

Norris, R. F., Flanders, T., Tomarelli, R. M. \& György, P. (1950). The isolation and cultivation of Lactobacillus bifidus : a comparison of branched and unbranched strains. J. Bact. 60, 681.

Pappenheimer, A. M. \& Hendee, IE. D. (1947). Diphtheria toxin. IV. The iron enzymes of Corynebacterium diphtheriae and their possible relation to diphtheria toxin. J. biol. Chem. 171, 701.

Pederson, C. S., Peterson, W. H. \& Fred, E. B. (1926). The forms of lactic acid produced by pure and mixed cultures of bacteria. J. biol. Chem. 68, 151.

Peters, J. P. \& VAn slyke, D. D. (1932). Quantitative Clinical Chemistry. Baltimore: The Williams and Wilkins Company.

Pine, L. \& Hardin, H. (1959). Actinomyces israelii, a cause of lacrimal canaliculitis in man. J. Bact. 78, 164.

Pine, L., Hardin, H., Roberts, S. S. \& Turner, L. (1960). Actinomycotic canaliculitis. A report of two cases with a review of the characteristics which identify the causal organism. Actinomyces israelii. Amer. J. Ophthal. 49, 1278.

Pine, L. \& Howell, A., Jun. (1956). Comparison of physiological and biochemical characters of Actinomyces spp. with those of Lactobacillus bifidus. J. gen. Microbiol. 15, 428.

Pine, L., Howell, A., Jun. \& Watson, S. J. (1960). Studies of the morphological, physiological and biochemical characters of Actinomyces bovis. J. gen. Microbiol. 23, 403.

Pine, L. \& Watson, S. J. (1959). Fivaluation of an isolation and maintenance medium for Actinomyces species and related crganisms. J. Lab. clin. Med. 54, 107.

Prévot, A. R. (1957). Manual de classification et de détermination des bactéries anaérobies, 3rd ed. Paris: Masson et Cie.

Rabinowitz, J. C. \& Barker, H. A. (1956). Purine fermentation by Clostridium cylindrosporum. I. Tracer experiments on the fermentation of guanine. J. biol. Chem. 218, 147.

Skerman, V. B. D. (1959). A Guide to the Identification of the Genera of Bacteria. Baltimore: The Williams and Wilkins Company.

Stanier, R. Y. \& Van Niel, C. F. (1941). The main outlines of bacterial classification. J. Bact. 42, 437.

Sundman, V., Buörkten, A. F. \& Gyllenberg, H. G. (1959). Morphology of the bifid bacteria (organisms previously incorrectly designated Lactobacillus bifidus) and some related genera. J. gen. Microbiol. 21, 371.

SuTER, L. S. (1956). Evaluation of criteria used in the identification of Actinomyces bovis with particular reference to the catalase reaction. Mycopath. Mycologia App. 7, 220.

Tasman, A. \& BrandwiJk, A. C. (1940). Experiments on metabolism with C. diphtheriae. III. J. infect. Dis., 67, 282.

Topley \& Wilson's Principles of Bacteriology and Immunology (1957). 4th ed. Ed. G. S. Wilson \& A. A. Miles. Baltimore: The Williams and Wilkins Company.

Umbreit, W. W., Burris, R. H. \& Stauffer, J. F. (1957). Manometric Techniques and Tissue Metabolism, 3rd ed. Minneapolis: Burgess Publishing Company.

van Niel, C. B. (1928). The Propionic Acid Bacteria. Haarlem: N. V. Uitgeverszaak J. W. Boissevain \& Company.

Waksman, S. A. (1961). The Actinomycetales. Vol. 2. Classification, Identification and Descriptions of Genera and Species. Baltimore: The Williams and Wilkins Company.

Wood, H. G., Stone, R. W. \& Werkman, C. H. (1937). The intermediate metabolism of the propionic acid bacteria. Biochem. J. 31, 349.

Woon, H. G. \& Werkman, C. H. (1936). Mechanism of glucose dissimilation by the propionic acid bacteria. Biochem. J. 30, 618.

Wright, J. H. (1905). The biology of the microorganisms of actinomycosis. J. med. Res. 13, 349. 
Journal of General Microbiology, Vol. 28, No. 2

Plate 1

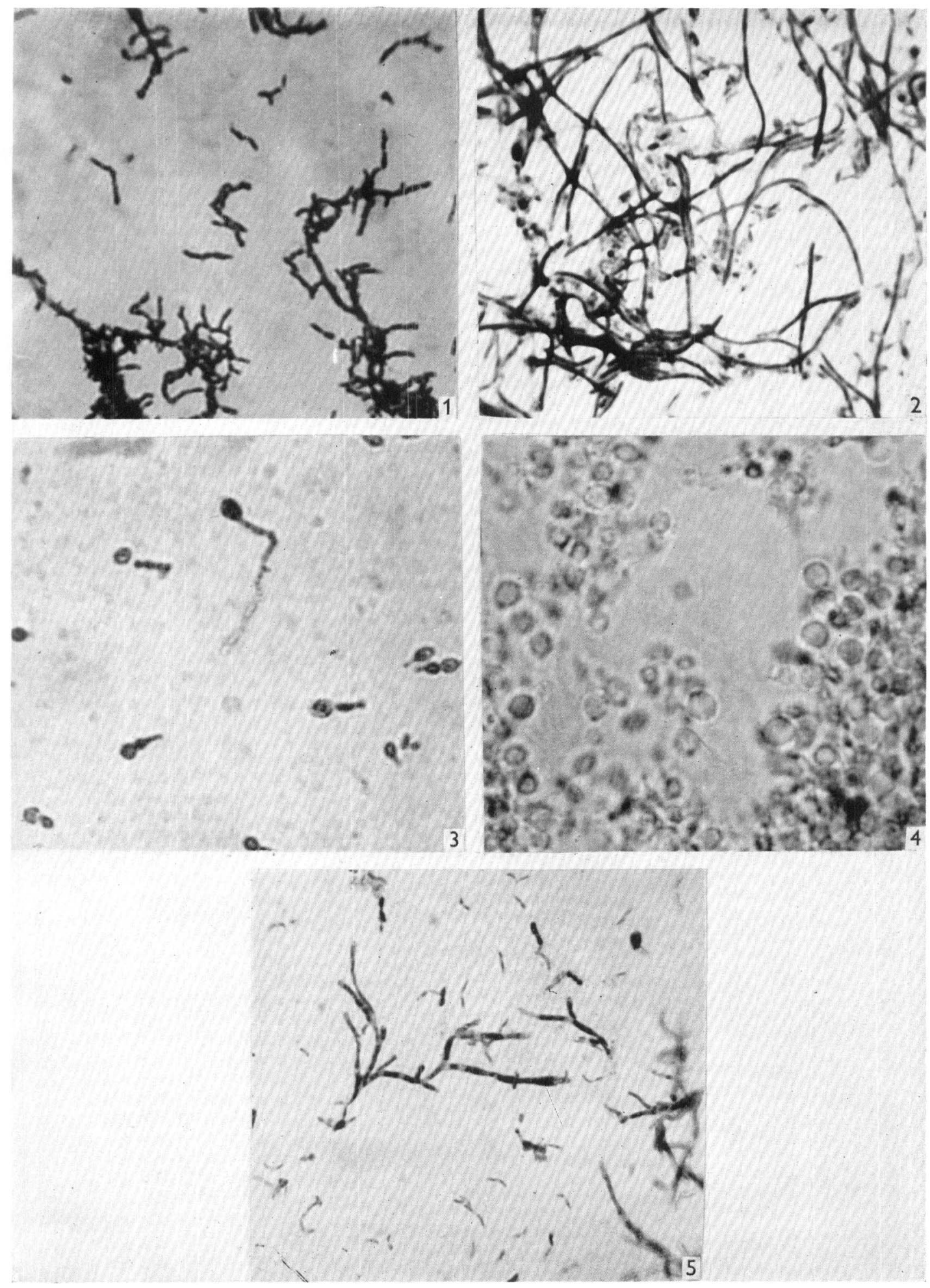



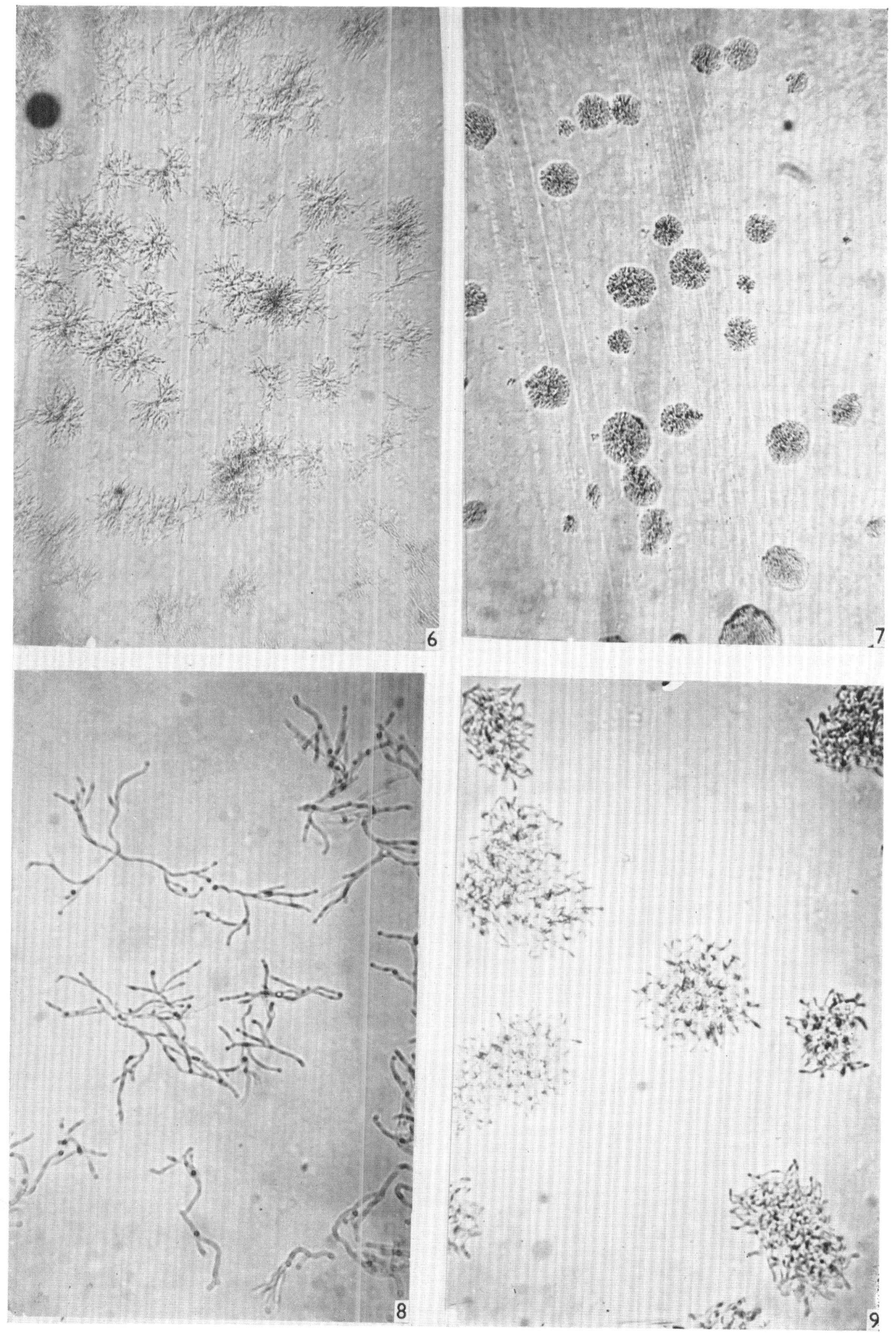


\section{Actinomyces propionicus}

\section{EXPLANATION OF PLATES}

\section{Plate 1}

\section{Cellular morphology of Actinomyces propionicus}

Fig. 1. Typical branching cells grown anaerobically for $72 \mathrm{hr}$. on $5 \mathrm{ml}$. of $1 \%(\mathrm{w} / \mathrm{v})$ glucose + Casitone medium. Gram stain, $\times \mathbf{9 7 0}$.

Fig. 2. Long filamentous forms grown anaerobically for $72 \mathrm{hr}$. in $1 \mathrm{l}$. fermentation flasks of $0.5 \%$ $(w / v)$ glucose + Casitone medium. Gram stain, $\times \mathbf{9 7 0}$.

Fig. 3. Typical organisms grown anaerobically for 10 days in $5 \mathrm{ml}$. of $1 \%(\mathrm{w} / \mathrm{v})$ glucose + Casitone medium showing terminal formation of spheroplasts. Methylene blue wet mount, $\times 970$.

Fig. 4. Cells grown for 10 days on $5 \mathrm{ml}$. of $1 \%(\mathrm{w} / \mathrm{v})$ raffinose + Casitone medium showing formation of greatly enlarged spheroplasts. Methylene blue wet mount, $\times \mathbf{9 7 0}$.

Fig. 5. Pus from lesion in mouse inoculated with A. propionicus. Mouse was killed after 33 days. Gram strain, $\times 970$.

\section{Plate 2}

Comparison of colony morphology of Actinomyces propionicus and Propionibacterium arabinosum

Fig. 6. Colonies of $A$. propionicus grown $24 \mathrm{hr}$. on $1 \%(\mathrm{w} / \mathrm{v})$ glucose + Casitone agar. $\times 100$.

Fig. 7. Colonies of $P$. arabinosum grown $24 \mathrm{hr}$. on $1 \%(\mathrm{w} / \mathrm{v})$ glucose + Casitone agar. $\times 100$.

Fig. 8. Colonies of $A$. propionicus grown $24 \mathrm{hr}$. on $1 \%(w / v)$ glucose + Casitone agar. $\times 430$.

Fig. 9. Colonies of $\boldsymbol{P}$. arabinosum grown $24 \mathrm{hr}$. on $1 \%(\mathrm{w} / \mathrm{v})$ glucose + Casitone agar. $\times 430$. 